\title{
GLOBAL WARMING - ITS CAUSES \& EFFECTS
}

\author{
Nalinakashi M.A.*, Nagaraja Rao. C. ${ }^{* *} \&$ \\ S. Sundareshan ${ }^{* * *}$
}

\section{ABSTRACT}

One of the most current and widely discussed factors, which could lead to the ultimate end of existence of Earth and man, is global warming and its devastating effects. Scientists have asked how fast the Earth is heating up, and how the warming effects on Earth may affect crops and climatic conditions. Several current trends clearly demonstrate that global warming is directly impacting on; rising sea levels, the melting of icecaps, and significant worldwide climatic changes. This article will i) explains the degree of destruction caused by global warming; contributing factors to warming, and ii) discusses what we can do to prevent the rate of increase in globol worming.

\section{Introduction}

Measurements of temperature taken by instruments all over the world, on land and at sea have revealed that during the $20^{\text {th }}$ century, the Earth's surface and lowest part of the atmosphere warmed up on average by about $0.6^{\circ} \mathrm{C}$. During this period, man-made emissions of greenhouse gases, including carbon dioxide, methane

* Department of Economics, Vijaya Degree College, Bangalore - 4.

* Department of Statistics, Vijaya Degree College, Bangalore - 4.

*** Department of Physics, Vijaya Degree College, Bangalore - 4 . 
and nitrous oxide have increased, largely as a result of the burning of fossil fuels for energy and transportation, and land use changes including deforestation for agriculture. In the last 20 years, concern has grown that these two phenomena are, at least in part, associated with each other. That is to say, global warming is now considered most probably to be due to the increases in greenhouse gas emissions and concurrent increases in atmospheric greenhouse gas concentrations, which have enhanced the Earth's natural greenhouse effect. While other natural causes of climate change can cause global climate to change over similar periods of time, computer models demonstrate that in all probability there is a real discernible human influence on the global climate.

If the climate changes as current computer models have projected, global average surface temperature could be anywhere from 1.4 to $5.8^{\circ} \mathrm{C}$ higher by the end of the $21^{\text {st }}$ century than in 1990. To put this temperature change into context, the increase in global average surface temperature, which brought the Earth out of the last major ice age, 14,000 years ago, was of the order of 4 to $5^{\circ} \mathrm{C}$. Such a rapid change in climate will probably be too great to allow many ecosystems to suitably adapt, and the rate of species extinction will most likely increase. In addition to impact on wildlife and species biodiversity, human agriculture, forestry, water resources and health all will also be affected. Such impact will be related to changes in precipitation (rainfall and snowfall), sea level, and the frequency and intensity of extreme weather events, resulting from global warming. It is expected that the societies currently experiencing existing social, economic and climatic stresses will be both worst affected and least able to adapt. These will include many in the developing world, low-lying islands and coastal regions, and the urban poor.

\section{Facts of Global Warming}

Global warming is caused by green house gases, which trap in the sun's infrared rays in the earth's atmosphere, which in-turn heat up the earth's atmosphere. These green house effect warming is called as global warming. The effects of green house effect are visible more prominently in the recent years, with the increasing natural calamities worldwide. The global warming has happened in the past few years and is evident from the rise in mean temperature of the earth's atmosphere. The main causes for the global warming are attributed to release of green house gases by human activities. The main gases contributing to green house effect are carbon dioxide, water vapor, methane and nitrous oxide. The largest producers of these gases are the thermal power plants, which bum the fossil fuels and produce these gases in large quantities. The second biggest sources of these green house gases are the road vehicles and industries. 
The global warming has led to increase in mean earth surface temperature and thus melting of polar ice. There are frequent melt down of glaciers that result in floods and other natural calamities. The melting of ice at the poles had led the mean sea level. Any further increase in temperature may further melt the ice and lead to further increase in mean sea level, which will engulf low lying countries.

The effect of global warming is very evident on the animal kingdom also. Some animals have become extinct due to loss of their natural habitat or their inability to evolve to the rapid changes in the climate. Also, there is a change in their life style because of the changes in the seasons. The migrating birds have changed their time of travel and also their place of migration.

The effect of global warming can be felt on seasons too. There is a shift in season cycle, as the summers are getting longer than the winters. This has affected the animals and made them to change their lifestyle accordingly, and those who failed to do so have perished or on the verge of extinction.

The global warming is also responsible for the introduction of some new diseases. The bacteria are more effective and multiply much faster in warmer temperatures compared to cold temperatures. The increase in temperature has led to increase in the microbes that cause diseases. Global warming is also effecting the crop production, as the crops are getting destroyed by the sudden change in temperatures or sudden onset of rains. Also, the flash floods and other natural calamities affect the crop.

As a matter of fact, because of global warming, the Earth's atmosphere is getting more unpredictable with heavy rains in the areas which have scanty rainfall or drought in the areas, which received good annual rainfall. The months of rainfall have also getting affected. But there are some people on the other side of the wall also, they believe that the global warming is a natural process and cannot disturb our ecosystem. The Earth's surface mean temperature was even higher a long time ago, and the ecosystem has evolved from that temperature to this. So, it can evolve further. But the changes that are happening now are rather fast compared to earlier times.

\section{Causes of Global Warming}

Global Warming is increasing the Earth's average temperature. The Green house gases are the main culprits of the global warming. The green house 
gases like carbon dioxide, methane, and nitrous oxide are playing hazards in the present times. These gases trap heat in Earth's atmosphere and thus result in increasing the temperature of earth. The excessive emission of these gases is the major cause of global warming.

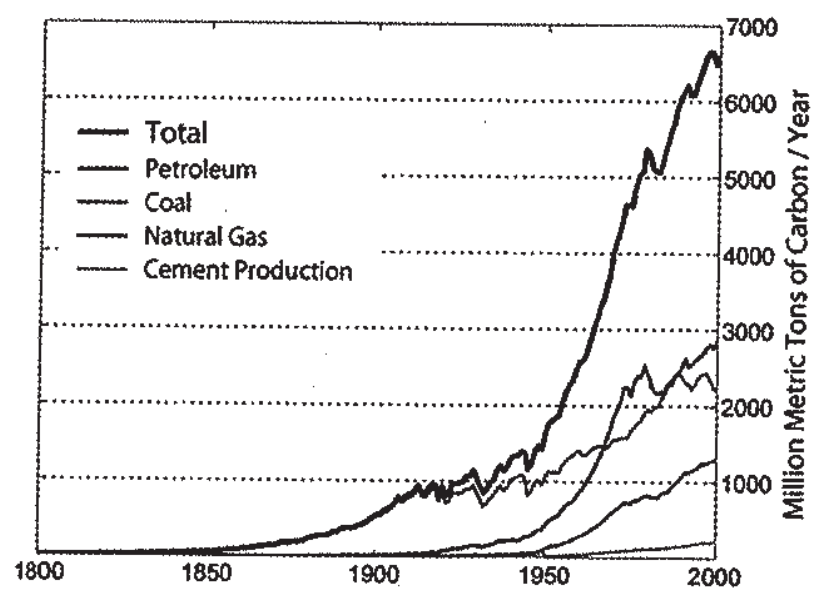

Fig. 1: Cause for global warming: Carbon dioxide emissions in million tons per year over the last 200 years.

The major source of carbon dioxide is the power plants. These power plants emit large amounts of carbon dioxide produced from burning of fossil fuels for the purpose of electricity generation. Coal is the major fuel that is burnt in these power plants. Fig. 1 explains this fact. Coal produces around 1.7 times as much carbon dioxide per unit of energy when flamed as does natural gas and 1.25 times as much as oil. The coal gives out $80 \%$ more carbon per unit of energy it produces as compared to natural gas. Another major source of carbon dioxide in the atmosphere is the emission from the cars and other vehicles. About $20 \%$ of carbon dioxide emitted in the atmosphere comes from burning of gasoline in the engines of the vehicles. This is true for most of the developed countries. Moreover if sports bike and vehicles that are essentially designed for rough terrain, emit more carbon dioxide when used for general purpose on roads. It is always better to use vehicles designed for city driving on the city roads. 
Fig. 2 Annual Greenhouse Gas Emissions by Sector

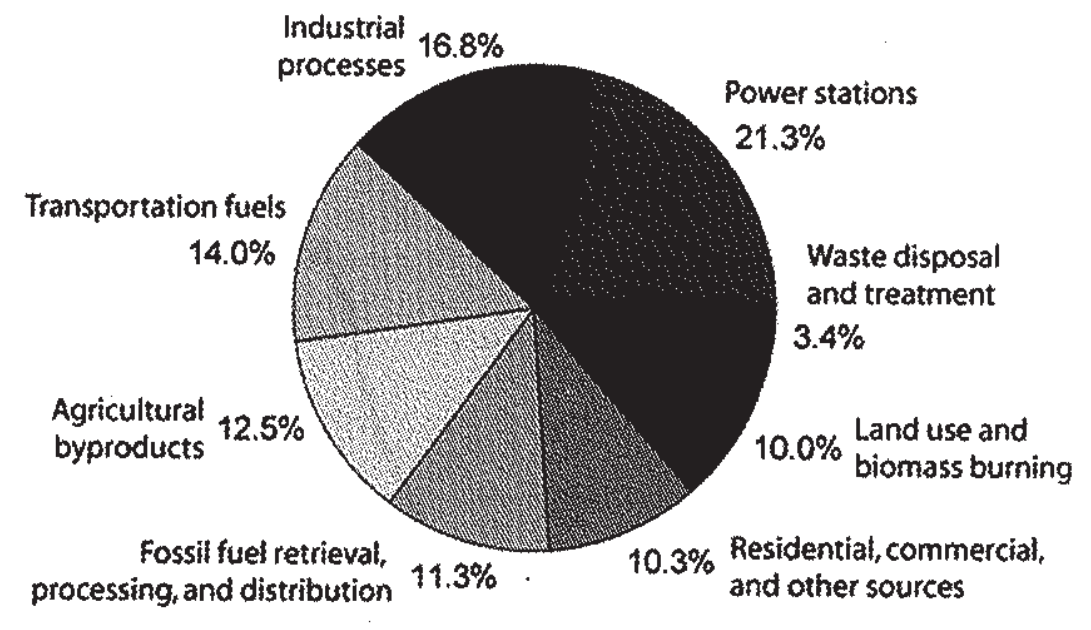

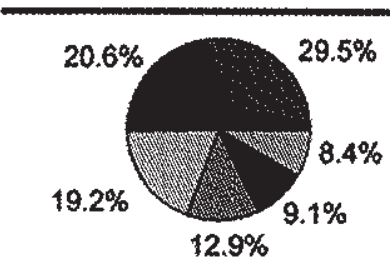

Carbon Dloxlde

(729s d touth

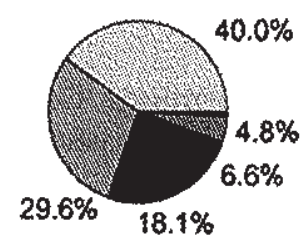

Methane it8\% of totso

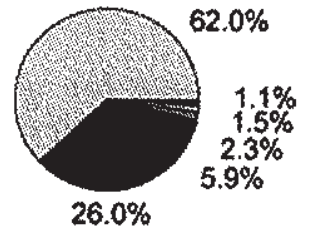

Nitrous Oxide

(20) of totsl)

Buildings, both commercial and residential represent a farger source of global warming pollution than cars and trucks. Building of these structures require a lot of fuel to be burnt which emits a large amount of carbon dioxide in the atmosphere. The second major greenhouse gas after carbon dioxide, which causes global warming, is Methane. Methane is more than 20 times as effectual as $\mathrm{CO} 2$ at entrapping heat in the atmosphere. Methane is obtained from resources such as rice paddies, bovine flatulence, bacteria in bogs and fossil fuel manufacture. Almost in all parts of the world, rice is grown on flooded fields. When fields are flooded, anaerobic situation build up and the organic matter in the soil decays, releasing methane to the atmosphere. Nitrous oxide, which is a colorless gas with a sweet odour, is another green house gas. The main sources of nitrous oxide include nylon and nitric acid production, cars with catalytic converters, the use of fertilizers in agriculture and the burning of organic matter. Greater emissions of nitrous oxides in the recent decades is leading global warming 
As the temperature and $\mathrm{CO}_{2}$ emissions continue to risk, the ideas that were ones the realm of science fiction-such as creating artificial trees to absorb $\mathrm{CO}_{2}$ or reflecting sunlight away from the earth, are coming under serious scrutiny. Another major cause of global warming is deforestation. Deforestation is to be blamed for $25 \%$ of all carbon dioxide release entering the atmosphere, by the cutting and burning of about 34 million acres of trees each year. Trees collect the $\mathrm{CO}_{2}$ that we breathe out and give away from various other sources, and they give back oxygen that we breathe in. Thus, cutting of trees is leading to greater concentration of carbon dioxide in the atmosphere. Greater urbanization, requirement of land for factories and buildings, requirement of timber are all reasons that are leading to deforestation, which in turn is leading to global warming.

\section{Greenhouse Gases}

Greenhouse gases are the ingredients of the atmosphere that add to the greenhouse effect. Some greenhouse gases are present naturally in the atmosphere, whereas few green house gases a consequence of human activity. The greenhouse gases that are present in the atmosphere naturally include water vapor, carbon dioxide, nitrous oxide, methane and ozone. There are a few human activities, which increase the levels of most of these naturally occurring gases. The concentration of various green house effect gases has substantially increased in the recent times. Greenhouse gases, which are the major cause of global warming, trap heat in the earth's atmosphere. Since the middle of the 19th century, human agriculture and industrialization have dispensed an enormous quantity of these green house gases into the atmosphere, where these have trapped enough heat to begin climate change. According to the United Nations, there has been a rise of about 0.6 degrees Celsius during the past century. More warming is expected to occur in the coming decades

The main reasons for the emission of gases that are a cause of green house effect are burning of fossil fuel like coal in the power plants for the purpose of generation of electricity. Fossil fuel burning leads to high emissions of carbon dioxide gas. Another green house gas is methane. Methane is more than 20 times as effectual as $\mathrm{CO}_{2}$ at entrapping heat in the atmosphere. Methane is obtained from resources such as rice paddies, bovine flatulence, bacteria in bogs and fossil fuel manufacture. Almost in all parts of the world, rice is grown on flooded fields. When fields are flooded, anaerobic situation build up and the organic matter in the soil decays, releasing methane to the atmosphere. Nitrous oxide, which is a colorless gas with a sweet odor, is also a green house gas. The main sources of nitrous oxide include 
nylon and nitric acid production, cars with catalytic converters, the use of fertilizers in agriculture and the burning of organic matter. A greater emission of nitrous oxides in the recent decades is leading global warming. Another jump in the category of green house gases is in the name of hydroflourocarbons and perflourocarbons, man made chemicals initiated as a substitute to other chemicals that deplete the atmosphere's protective ozone layer. Fig. 2 provides sector-wise contribution of annual greenhouse gas emission.

The speedy increase in greenhouse gases over the past century is a matter of worry in at least 800,000 years, according to a study of the oldest Antarctic ice core. Scientists at the British Antarctic Survey (BAS) in Cambridge have established the fact that there have been eight cycles of atmospheric alterations in the past 800,000 years when green house gases like carbon dioxide and methane have risen to high levels. Each time, the earth also had a comparatively high temperatures linked with warm; inter glacial periods, which were most certainly associated with levels of carbon dioxide and probably methane in the atmosphere. However, present levels of green house gases are much higher than everything seen during those previous warm periods.

Although much is being done to reduce the emission of these greenhouse gases, but the efforts are still not enough. An international agreement called the Kyoto Protocol has been made among the various nations to cut down the emission of these gases. There is a dire need that each one understands the ill effects of these green house gases and does the need full.

\section{Measures to control Global Warning}

There are several things which we can do after reading this article. However, some of the actions which we all have to take will slightly decrease your present standards of living.

1) Firstly, since the largest portion of electricity in the US is produced by burning coal, we should try to cut-down on our demand for electricity. Coal combustion creates the largest amount of $\mathrm{CO} 2$ per energy unit of any fossil fuel. Coal and oil together represent $80 \%$ of the US fuel supply used to generate electricity. When we reduce electric power use, we save money, breathe cleaner air, and help to reduce the global warming problem. Every kilowatt-hour of electricity saved keeps 1.5 to 2 pounds of $\mathrm{CO}_{2}$ out of the atmosphere. Americans waste more energy than any other nation. It is time to make our lives, factories, and homes more efficient. Look around at home, and at your work place, and you 
will find several ways in which you can decrease the use of electricity. For instance, plant several trees on the south side of your house where they can give shade during the hot summer months. Also, install an energy efficient thermostat, with a day and night timer.

2) Secondly, decrease the use of your car. If you can't afford to buy a new fuelefficient car in the next few years, consider selling or junking your gas demanding car and buying a smaller, efficiently used car. Besides saving money on gas, oil, tires, parts, and repairs, you can help reduce greenhouse gases. Furthermore, no matter what type of car you drive, be sure to operate it efficiently, try to carpool to work or ride the bus, keep the car tuned up, walk or ride your bike for short distances, park and walk do not use "drive thru" services.

3) Thirdly, try to follow the following environmental policy of "Reduce... Reuse.... Recycle." Reuse of anything is the easiest and best way to recycle. Save containers, bags, everything that you may be able to use in the future. Also, use cloth towels and napkins instead of paper ones, and use rechargeable batteries instead of disposable ones.

4) Also, you can reduce the need to recycle paper by getting off the junk mail lists. Why should trees be destroyed for mail you do not even want to receive? In addition, always remember that recycling is only effective when you buy products made from recycled materials. Otherwise, what is the point of recycling?

Further, each time you make a purchase, you either reinforce a bad environmental product, or you encourage a good one. I believe that people should try to buy quality products that can be used for a long time, buy products with minimal packaging, and not buy disposable products. We certainly have to make-up our minds whether our success as an individual should not be based on the quantity of our consumption, or on the quality of our natural environment. According to Professor Launder of Manchester University, Extracting carbon from the atmosphere would be too slow a process to prevent warning. Better is to make clouds brighter, which increase the sunlight reflection especially in the pacific where the ocean temperature has great influence on world climate (TOI, 16.03.09).

We believe that it is time to examine our moral values. Also examine our attitudes as they relate to our natural world. Each of us needs to ask ourselves: What makes us really happy? What makes us feel secure? It is highly questionable if money and tangible objects make us more happy, it is even possible that we tend to be less happy with our life's when we have a lot of tangible objects and money to care for. Has our striving for more and more materialistic consumption caused us to forgef that we are living human beings? We have to realize that we have much more in 
common with the plants, animals, air and water than we have with the mechanical, chemical and electronic world we have created around us. The Chinese proverb which says "If you plan for one year, plant rice, if you plan for 10 years, plant trees and if you plan for 100 years, then educate people", makes real sense.

Unfortunately, the disbalance which we have created between our life's and the Earth is already showing the signs of disaster. "Earth in the Balance" is moving to the Earth in imbalance, which, in the long run will cease to exist. Remember, we are all in the greenhouse together, nobody can stop the world and get off.

\section{Discussion}

The threat of devastating climate is now so great that some scientists say it is time to take stringent measures which prevents further warming. Global warming is the phenomenon in which there has been an increase in the average temperature of the earth's atmosphere and oceans in last few decades, and its predictable extension. The increase in the earth's average temperature can further cause other alterations, including an increasing sea level and alterations in the quantity and model of precipitation. These alterations may raise the incidence and concentration of tremendous weather proceedings, such as floods, famines, heat waves, storms, and cyclones. Other costs can comprise of higher or lower farming yields, glacier withdrawals, lesser summer stream flows, genus extinctions and boosting in the ranges of sickness vectors.

It is very important that proper heed is paid towards the global warming problem. Unless we get alert quickly to deal with the fundamental reasons of global warming, our world will experience a thread of awful calamities, including more and stronger hurricanes like the one Katrina, in both the Atlantic and the Pacific. A fact that it is due the global warming that the North Polar ice cap and all the mountain glaciers in world will finally melt down in a few decades from now. The amount of carbon dioxide that is being dumped in the environment has literally changed the relationship between the earth and the sun. So much of that $\mathrm{CO}_{2}$ is being engrossed into the oceans that if we carry on at the present rate we will increase the saturation of calcium carbonate to levels that will stop formation of corals and impede with the making of shells by any sea creature.

We need to take proper steps to cut down global warming. The growing of switch grass and saw grass should be encouraged. Switching to a greater extent on ethanol, cellulosic ethanol, butanol, and green diesel fuels can also reduce global warming pollution. On a universal basis, about more than two trillion tons of the 10 trillion tons of $\mathrm{CO}_{2}$ emitted each year comes from flaming the forests. So, improved 
organization of forests is one of the single most significant strategies for solving the climate disaster. Sources like wind energy, solar energy should be made in common use. Since in 1991, the Supreme Court of India issued directive to make all curricula environmental oriented, there is a need to make all the persons environmentally educated. If proper steps are nof taken today against global warming, it will get too late to do anything.

\section{References}

1. Allaby, Michael. A change in the weather. New York, Facts on File, c2004.

2. Brightend cloud to fight warming?, a report in Times of India dated 16.03.2009.

3. Climate change: science, strategies, \& solutions. Edited by Eileen Claussen, Vicki Arroyo Cochran, and Debra P. Davis. Leiden, Boston, Brill, c2001. 399 p.

4. Hardy, J. T. Climate change: causes, effects, and solutions. New York, J. Wiley, c2003. 247 p.

5. Houghton, John Theodore. Global warming: the complete briefing. 3rd ed. Cambridge, Eng., New York, Cambridge University, 2004. 351 p.

6. John J. Berger. Beating the Heat: Why and How We Must Combat Global Warming. Berkeley, CA: Berkeley Hills Books, 2000.

7. Maslin, Mark. Global warming: a very short introduction. Oxford, New York, Oxford University Press, 2004. 162 p. Nery short introductions, no. 118)

8. Melvin A. Benarde. Global Warning - Global Warming. New York: Wiley, 1992.

9. Nigel Arnell. Global Warming, River Flows and Water Resources. Chichester, England: Wiley, 1.996.

10. Roger Bate and Julian Morris. Global Warming: Apocalypse or Hot Air? London: Institute of Economic Affairs, 1994.

11. Ronald Bailey, ed. Earth Report 2000: Revisiting the True State of the Planet. New York: McGraw-Hill, 2000. 